Article

\title{
Governing Spatial Disparities in School Infrastructure by Numbers: Investments in Form, Tensions, New Compromises?
}

\author{
Walter Bartl (iD)
}

Citation: Bartl, W. Governing Spatial Disparities in School Infrastructure by Numbers: Investments in Form, Tensions, New Compromises? Educ Sci. 2022, 12, 167. https://doi.org/ 10.3390/educsci12030167

Academic Editors: Regula Julia Leemann, Irene Kriesi and Rita Nikolai

Received: 12 October 2021 Accepted: 22 February 2022 Published: 28 February 2022

Publisher's Note: MDPI stays neutral with regard to jurisdictional claims in published maps and institutional affiliations.

Copyright: (C) 2022 by the author. Licensee MDPI, Basel, Switzerland. This article is an open access article distributed under the terms and conditions of the Creative Commons Attribution (CC BY) license (https:// creativecommons.org/licenses/by/ $4.0 /)$
Institute of Sociology, Martin Luther University Halle-Wittenberg, 06108 Halle (Saale), Germany; walter.bartl@soziologie.uni-halle.de

\begin{abstract}
Given that education infrastructure has been a crucial element of the infrastructural power of the welfare state, surprisingly little is known about how spatial disparities in school infrastructure have been governed. While emphasis has recently been placed on the role of numbers in governing the education system, there have been contradictory results on the use of numbers for measuring spatial disparities in schooling on the one hand and on allocating school infrastructure by numbers on the other. What role have indicators played in the governance of regional disparities in education and how can we explain changes to this role? Assuming that indicators typically fulfil two functions in decision making processes (information gathering and allocation of resources), this article develops an ideal-typical distinction between four ways of (not) using numbers for governance purposes. This typology is applied to a historical case study of indicators as a device for governing spatial disparities in education in Germany. Cognitive investments in indicators for observing spatial disparities in education and for administering schools have been made in Germany since the early 19th century. However, conceptual flaws and conservative education policies have kept them from being put to effective practice in school infrastructure policies. It was not until the 1970s that demographic and administrative indicators became institutionalized as part of decentralized but fairly standardized school planning practices. While the use of indicators in the spatial allocation of education resources seemed to work well during periods of educational expansion, this calculative practice produced tension with the civic idea of spatial justice when enrolments declined.
\end{abstract}

Keywords: quantification; regional disparities; governance; spatial justice; territorial politics; education infrastructure; economics of convention

\section{Introduction}

The global expansion of mass education, especially in the second half of the 20th century, could give the impression that spatial disparities in education are no longer relevant. Scholars of World Polity Theory have crucially pointed out how educational institutions have become diffused worldwide. Yet their argument is typically based on comparisons between nation states and ignores the aspect of spatial disparities in education within states [1]. Spatial disparities are particularly problematic from the normative point of view of the welfare state because they contribute to educational poverty and increase the likelihood of social exclusion. Regions with poor education infrastructure literally hamper access to education in a physical sense. While the expansion of secondary schools in Germany, for example, seems to have contributed to a reduction in spatial disparities, place of residence remains a decisive factor in educational attainment [2]. Spatial disparities contradict the claim of welfare states to provide social rights in the sense of universal and fair access to education for all citizens. In order to substantiate the claim of universal access to education, modern states are expected to implement policies and governance mechanisms aimed at reducing spatial disparities. Indicators are not only crucial for measuring spatial disparities, they very often also regulate the spatial planning and allocation of educational resources such as material infrastructure, personnel, or public moneys. By providing 
quantitative information and regulating the allocation of resources, indicators contribute to the communicative construction and socio-material constitution of social space [3]. The purpose of this article is to analyze the dual role of numbers in formalizing governance processes, namely as instruments for gathering information and allocating resources. While indicators have recently been portrayed as instruments for monitoring education that proliferate, their actual use in the governance of spatial disparities is controversial. At the same time, indicators, which have been instrumental in processes for closing down schools, have attracted the rather limited but often critical attention of scholars. Where do these apparent key indicators of legitimate school size actually come from? Although economists (implicitly) take for granted the calculative practice of de-allocating school infrastructure, sociologists highlight the historical contingency of these calculations and point to the possible consequence of increasing spatial disparities. How can we conceptualize the different roles that numbers play in the governance of spatial disparities in education and how can we explain the observed variations? Analytically, the article builds upon recent contributions to the sociology of space, the emerging field of Quantification Studies as well as on the author's own research in the tradition of Grounded Theory. Empirically, the article focuses on the history of indicators for measuring spatial disparities in schooling as part of official statistics and on school planning as a calculative form of allocating education infrastructure by numbers in Germany. While standardized indicators for measuring spatial disparities in schooling at the sub-national level have basically remained the domain of highly specialized research, calculative school planning was in fact institutionalized during the 1970s. This was preceded by more than a century of very limited investment in the development of educational indicators of spatial disparities in official statistics and by a lack of documented calculative use of indicators for the allocation of school infrastructure. The institutionalization of school planning was facilitated by a convergence of arguments pertaining to social citizenship rights and economic efficiency and by initial signs of the distinction between the rural and urban losing the quasi-natural plausibility it had in the long 19th century. However, soon after its institutionalization, calculative school planning faced the downside of "statistical rules" when declining enrolments called their purely arithmetic application into question.

This is followed below by an elaboration of the theoretical background of the analysis and an analytical typology. Afterwards, the typology will be used for a historical analysis of the (lacking) role of indicators in governing regional disparities in the German education system. Due to the fairly long timespan covered, the empirical analysis does not aim to give a complete account of the historical trajectory of indicators as a (potential) device for governing spatial disparities in education but will instead focus on two periods (the 19th century and the late 20th century) which will demonstrate the analytical fruitfulness of the typology. The empirical part is based on a secondary reading of existing but previously unrelated works.

\section{Governing by Numbers and Spatial Disparities in Schooling}

The brief discussion of literature in this section will identify the desiderata of research which my own approach will strive to overcome.

\subsection{Spatial Disparities in Schooling, Education Monitoring, and School Planning: Varying Roles of Numbers and Missing Links}

A desideratum in education research is created by the ample evidence of processes of global educational expansion provided by World Polity scholars [4]. World Polity scholars assume that the expansion of the education system is legitimated by the values of universalism and rationalization. In terms of the latter, scientific knowledge links education to economic development and provides scripts for efficient education planning that are distributed by international organizations [5] (p. 136). However, this view has provided little evidence on how scientific knowledge and planning instruments are put into practice in local processes of political and administrative decision making. While 
neoliberal policy scripts assign indicators a crucial role in the "epistemic governance" of the education system [6], research on spatial disparities in schooling has repeatedly bemoaned that there are not enough detailed and intertemporally consistent (official) data on a spatial scale relevant for pupils in Germany [2]. Education monitoring at the national level does not regularly provide information on a spatial scale below the state level [7]. Although municipal reports on education have increased considerably, they rarely seem to be utilized in policymaking [8]. Research on the non-use of indicators is relatively scarce [9]. When monitoring indicators become more formally linked to the identification of disadvantaged schools and a compensatory allocation of resources [10] (p. 6), questions about civic spatial justice as well as dilemmas of resource allocation and stigmatization emerge. Quantification also plays an important role in administrative decisions on school closures and, hence, in spatial disparities in education. In some countries, such as the United States, for example, indicators of low educational performance have become linked to school closures as an ultimate measure of turnaround management, increasing the stakes of testing for schools [11]. In other countries, such as Germany, testing has not been related to formal sanctions (yet). School closures have instead been driven by "school size policies" [12] as a response to demographically induced enrolment declines [13-15]. However, it has remained unclear how indicators of school size have acquired their role as key administrative indicators.

Focusing exclusively on recent developments tends to ignore, firstly, the possibility that numbers might have been relevant for school infrastructure policies for much longer. Secondly, despite the omnipresence of numbers in educational matters, as has variously been pointed out, the relative scarcity of small-scale information on spatial disparities in schooling is surprising. Thirdly, the distinction, as well as the potential links, between measuring spatial disparities in schooling, on the one hand, and constituting social space in a socio-material sense on the other has yet to be properly conceptualized. The following section will describe how the use of indicators for the governance of spatial disparities in school infrastructure can be conceptualized more precisely by distinguishing between their roles in information gathering and allocation in decision making processes.

\subsection{Decision Making Based on Indicators: Information, (E)Valuation, Allocation}

Although indicators have been conceptualized as instruments with various functions, the variable links between information and control still await proper conceptualization [16]. Below, I draw upon crucial contributions to the emerging field of Quantification Studies in order to address this caveat. Writing at the point where Economics of Convention and ActorNetwork Theory intersect, Alain Desrosières adheres to the idea that statistical objects of knowledge are based on methodological conventions and need continuous stabilization by a socio-material environment in order to act as unquestioned black boxes in social interaction. Statistics cannot be produced without investments in methodological conventions and organizational infrastructure, such as in France between 1789 and 1795, when nationwide censuses and surveys failed [17] (p. 31). Furthermore, without accompanying concepts and state interventions, the contingency of statistical objects would become obvious [18]. New measures often build upon existing forms in order to take advantage of previous investments [19]. For example, indicators on spatial disparities very often create consistency with their institutional environment by building upon territorial distinctions of the state. Indicators achieve the status of objective information instruments by abstracting from local conditions. During the process of quantification, the plurality of possible viewpoints is reduced by rules of data gathering that standardize the observation process. This standardization is achieved by sacrificing detail and context sensitivity [20] (pp. 50-56). The resulting numbers contain chains of reference which theoretically allow the process of abstraction to be traced backwards [21]. However, this would require time, which is why numbers are often accepted rather than questioned [22].

Indicators are a particular form of numbers. Although there is no consensual definition of what an indicator is, a frequently mentioned attribute is that they are numerical 
representations of relevant phenomena tailored to inform (political) decision making [23]. According to Theodore Porter and Wendy Espeland, the use of indicators tends to mechanize political and administrative decision making because it is a means of imposing rules on subjective judgement [24,25]. Processes of decision making can be analytically divided into the stages of information gathering, evaluation, and the allocation of resources or liabilities. Indicators that are used during one or more of these stages are likely to mechanize decision making, firstly because of their standardized production process that evinces a certain representation of the subject at hand and secondly because they reduce personal discretion in the allocation of resources once they become (formally) institutionalized [26] (p. 316). Rule-based quantitative observations lead to apparently unambiguous results. These contain an evaluative element in the sense that a numeric value is attributed to an object. Hence, the information function of indicators conceals the evaluative dimension of numerically objectified results [22]. Rule-based quantitative allocations are crucial for democratic control of public action [27] as they create transparency for third parties [28]. Formal allocation criteria based on indicators correspond to the implementation of a "statistical rule" rather than personal discretion [29] (p. 55). However, it is important to note that formal quantification does not take place in a world devoid of numbers; instead, it builds upon mundane practices of counting and calculation [30]. Even in more elaborate forms, the use of numbers can remain subject to personal discretion [24]. When quantification becomes more standardized, it still retains many instances where judgement is required. According to Porter, it is mainly weak professional groups that become subject to quantified rules, but national traditions of public accountability might also be relevant [25]. When quantitative information is publicly available, it opens up two options for critique: realist and relativist [17] pp. 335-337 and [31]. The realist option uses numbers to hold officials accountable for the represented reality; the relativist critique is directed against the quantitative representation itself. Both forms of critique open up situations for new decision making [20].

\subsection{Using Indicators to Construct and Constitute Spatial Disparities in School Infrastructure}

When analyzing spatial disparities in education it is useful to distinguish between the communicative construction and the socio-material constitution of space [3,32]. On a representational level, scientific research that strives to measure spatial inequalities in education typically relies on quantitative indicators, which very often means a translation of potentially plural spatial figurations into a territorial scheme. A territorial scheme might be chosen because of the availability of official data but also because this scheme has become a common way of constructing space in society, thus offering a quasi-natural register of equivalence. The quantification of spatial inequalities in education adds a new objective layer to reality, a discursive frame that can become the basis for decision making (or not). Therefore, measuring spatial disparities using territorial indicators can be regarded as a form of "epistemic" governance [6]. However, measurement alone does not constitute space in a socio-material sense. School infrastructure does constitute space in a socio-material way because it creates a place in a specific location where formally organized physical interaction can take place. Symbolic representations of space might be related to the socio-material constitution of place through school infrastructure, but this relationship varies.

States seem to be likely actors in measuring spatial disparities as well as crucial actors in constituting social space through school infrastructure [33]. According to Michael Mann, the power of the modern state lies in its ability to provide society with coordinating capacities throughout its territory [34]. An important part of these coordinating capacities are education services provided through socio-material infrastructures (buildings, technical networks, staff, and organizational routines) that allow for the systematic creation of interactive teaching-learning situations. How can we conceptualize the organization of school infrastructure by the state? 
Decision making - in organizations in general and in the public sector in particularhas to deal with competing orders of worth $[35,36]$. Similarly, the organization of education infrastructure is often confronted with contradictory normative claims [37] p. 122 and [38]. A historically evolving set of competing orders of worth has been identified within the Economics of Conventions [36,39]. Some of them seem to apply more than others to the governance of school infrastructure by numbers [38]. While civic norms require the education infrastructure to be allocated in a spatially equitable way, industrial norms of efficiency expect schools to produce a reliable regional or national workforce and capable leaders for the future. The order of the domestic world emphasizes the relations a school has with its local environment, whereas a market view typically regards families as consumers that want to and can make choices that are largely irrespective of spatial distances. As school systems often lack price signals, these can be supplemented by school league tablestypically at the local level. School league tables demarcate a geographically identified field of competing schools, creating prestige for schools at the top and stigmatizing schools at the bottom. This formally translates into expectations surrounding the reputation of particular schools [40]. The network order of worth requires schools to build and maintain flexible project-based cooperative relationships with stakeholders in their functional social environment-potentially on a global scale.

\subsection{Distinguishing between Different forms of Governing by Indicators}

In order to analyze the use of indicators in educational governance, this article conceives of governance as rules and practices that regulate, first, the observation and evaluation of objects and persons and, second, the allocation of rights, resources, and obligations considered relevant to the problem at hand (in our case: formal education processes for the school-aged population). While Desrosières presents many historical examples where quantitative description and state action match [18], research on the non-use of (education) indicators shows that this is not necessarily the case $[8,9]$. In order to capture this variance more systematically, I propose the construction of a heuristic property space [41].

Combining the information and allocation dimensions of educational governance results in a heuristic distinction of four different types of decision making processes that rest to a varying degree on the systematic use of indicators (Figure 1).

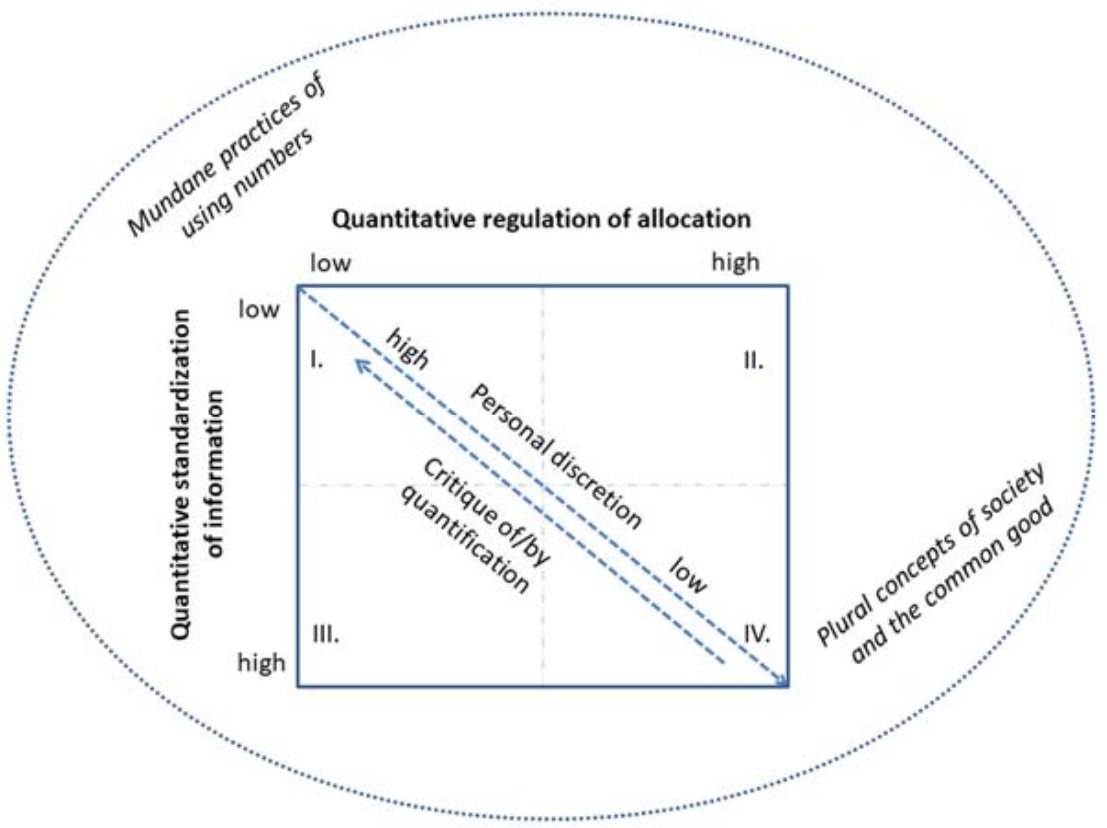

Figure 1. Heuristic distinguishing between four types of governing decision making through quantification: I. discretionary quantification; II. bureaucratic quantification; III. epistemic quantification; and IV. calculative quantification. Source: author. 
The typology starts from the assumption that formal quantification decreases the degree of personal discretion in making observations and allocating resources [24,25].

Type I (discretionary quantification) represents decision making that might be regulated by professional standards and formal rules, such as laws [25], but does not rely in a systematic way on quantification for information gathering or allocation. While the use of numbers had long been common practice before national statistical systems began to formalize enumeration practices [30], generalizing a form of counting beyond local use requires investments [17,19]. Interest in such investments increases when interaction chains become longer, for example because the interests of third parties are considered [24,28]. The application of standards and rules always retains an aspect of personal discretion, yet, in contrast to verbalized formal rules, quantified standards and rules restrict discretion to a greater degree as they are more precise. Social fields vary in the degree to which they systematically rely on expert judgement instead of quantification, and often for good reason. For example, the field of law has resisted quantification to a significant extent [25]. In the education system, discretion is not merely a source of personal power for pedagogical professionals and administrators but might actually be genuinely valued during political negotiations. In disputes, personal discretion is protected by arguments of incommensurability of various shades [26]. On a structural level, institutionalized categories representing different qualities are a means of inhibiting commensuration. The school systems of the German (federal) states, for example, were basically incommensurable throughout the 19th century and still are notorious for being hard to compare in a systematic way $[42,43]$. It is debatable whether the current relative epistemic non-transparency has been strategically created [44] (pp. 143-147) or whether it is instead the outcome of historical path dependencies.

Type II (bureaucratic quantification) represents decision making in which readily available numbers are used to create object categories to which certain resources or liabilities are formally allocated. Continuous values (mainly based on mundane counting) are transformed into a nominal distinction. For this type of quantification, investments in form are usually minimal as the numbers often already exist as a byproduct of daily administrative business or of local practices. For the typology, it does not matter which judgements or expertise a numerical threshold has been based on-although that might be of utter practical importance for its legitimacy. What is decisive is that the threshold becomes part of a formal rule, which makes it an objectified and sanctioned part of reality. Unlike continuous indicators, nominal distinctions do not change their values very often; therefore, this is a relatively static form of resource allocation, which might also become the basis for identity formation. Classifying settlements based on population size, for example, can give rise to place identities within an urban system, such as being a "small town" for example. In the field of education, typical examples of bureaucratic quantification are numerus clausus policies, minimum enrolment thresholds as administrative criteria for the organizational viability of schools, as well as class sizes. As a management device for head teachers, class thresholds indicate when to create or disband a class. Based on simple counting, they render the individual class an indivisible good. Nevertheless, third parties might apply more elaborate calculation methods, rendering the class a continuous good and comparing it to other, more distant classes using different registries of equivalence. Financial administrators, for example, regard average class size as a physical indicator of cost efficiency; professional teaching bodies interpret it as an indicator of working standards [45] (pp. 39-40). As long as the indicator is not questioned, it embodies a compromise between these views. An investment into the standardization of further quantification for mere information purposes pushes the situation towards Type III. Investments into further quantification and formal sanctions move the situation closer to Type IV. Which numerical criteria apply to schools in a certain polity affects spatial disparities because higher thresholds of organizational viability will be more difficult to reach in rural areas than in urban ones.

Type III (epistemic quantification) represents constellations in which indicators are used systematically for information gathering and (e)valuation but which do not connect the 
quantitative results of these processes formally to the allocation of resources and liabilities. Traditional statistics on education could be seen as enacting a rudimentary form of epistemic quantification because they introduced a certain coherence of classifications and standardized quantification for public information purposes that went beyond internal administrative statistics [46]. However, additional criteria are useful to further sharpen this ideal type. Starting from a critique of official statistics on education, the density and specialization of quantitative observations have recently intensified [6,18]. In constellations of epistemic governance, education indicators are not mainly produced by (national) statistical offices, instead an increasing number of actors invest in the definition and production of additional, more elaborate, and supposedly more relevant indicators. Furthermore, these indicators are publicized more widely than traditional official statistics. When reports or rankings become more serial in terms of periodicity and indicators used, they can form a coherent monitoring system with a substantial power of constructing educational reality [47] pp. 150-152 and [48]. When education reports point out spatial disparities, they can influence policy formulation by making them politically more salient. However, producing key indicators that are considered relevant by various audiences is not an easy task, nor is it the case that investments in the production of more indicators preclude the risk of non-use (e.g., because of information overload) or critique [23]. In constellations of purely epistemic quantification, no criteria of allocation are tied to the observation of spatial disparities. Instead, allocation decisions rely on political or professional judgement as well as political negotiations. Some argue that spatial disparity indicators "cannot be applied mechanically" because they require interpretation [45] (p. 63). In contrast, when an equivalence space between information and allocation has been formally defined, a mechanical relationship is precisely what is desired, such as with social indices for schools in Germany [49]. However, when properly considered, this case already falls under the next ideal type.

Type IV (calculative quantification) identifies cases in which indicators are institutionalized for purposes of information gathering and evaluation as well as for the allocation of resources and liabilities. Furthermore, both functions are connected to each other by formal rules or by routinized practices. More precisely, when indicators of information gathering take on a certain value, particular allocative routines are catalyzed in a quasi-automatic way. The highest degree of calculative quantification is reached when information indicators and allocation indicators are connected through a mathematical formula. Therefore, indicators on a ratio scale of measurement are needed for this ideal type. In Poland, for example, the amount of central state subsidies to local governments for education purposes is determined by the number of pupils enrolled in their area; when enrolments increase, so do subsidies [50]. Another example of coupling quantitative representation with routines of allocation can be found in school planning, although they operate in a less mechanical way than the rules of the fiscal federalism procedures. Unlike monetary calculations, calculating the school infrastructure of a planning region contains indivisible and more complex sociomaterial elements and typically also entails more judgmental discretion and political debate. The latter is evident, for example, in the considerable variance in the elasticities of schools to declining enrolment [51]. By calculating education demand and supply structures in-kind (based on physical indicators), decisions on school infrastructure typically strive to strike a balance between civic spatial justice and efficient resource allocation. These routinized decisions obviously affect spatial disparities because they determine the accessibility of schools. While planning procedures for school infrastructure certainly represent a less strict form of calculative apportionment than fiscal allocation rules, they display a similarly mechanical logic-especially when adaptations to demographic change approach proportionality. However, like any other form of quantification, calculative quantification might become subject to critique, which usually opens up situations for new decisions [13].

The four ideal types of governing educational disparities by numbers roughly correspond to some of the historically varying forms of state intervention in the economy as identified by Desrosières, most clearly with regard to the welfare state, the Keynesian state and the neoliberal state [18]. According to Desrosières, law and statistics are two 
general and distinct forms of constructing the state [17] (p. 8). Yet, sometimes numbers become part of law (or lawlike regulations), situations that seem particularly relevant and accounted for by Type IV of the proposed heuristic. Furthermore, while Desrosières acknowledged situations in which quantification failed because of a lack of investment in form, he apparently saw little reason to pay attention to situations in which quantification is deliberately avoided (discretionary quantification). Moreover, coming mainly from a diachronic analysis of the state, he did not develop a very explicit notion of possible conflicts resulting from coexisting orders of worth during processes of decision making [35] (Table 1).

Table 1. Ideal types of quantification and compatible state forms as well as compatible orders of worth. Source: author.

\begin{tabular}{|c|c|c|c|c|}
\hline & $\begin{array}{l}\text { I. Discretionary } \\
\text { Quantification }\end{array}$ & $\begin{array}{l}\text { II. Bureaucratic } \\
\text { Quantification }\end{array}$ & $\begin{array}{l}\text { III. Epistemic } \\
\text { Quantification }\end{array}$ & $\begin{array}{l}\text { IV. Calculative } \\
\text { Quantification }\end{array}$ \\
\hline $\begin{array}{c}\text { Quantitative } \\
\text { Standardization }\end{array}$ & low & low & high & high \\
\hline $\begin{array}{l}\text { Quantitative } \\
\text { Regulation }\end{array}$ & low & high & low & high \\
\hline Example & $\begin{array}{l}\text { Great variety of } \\
\text { incommensurable } \\
\text { school types }\end{array}$ & $\begin{array}{l}\text { School size } \\
\text { thresholds }\end{array}$ & $\begin{array}{l}\text { Education } \\
\text { monitoring }\end{array}$ & $\begin{array}{l}\text { School } \\
\text { planning }\end{array}$ \\
\hline $\begin{array}{l}\text { Judgmental } \\
\text { Discretion }\end{array}$ & high & intermediate & intermediate & low \\
\hline $\begin{array}{l}\text { Compatible } \\
\text { state forms }\end{array}$ & & Welfare state & Neoliberal state & Keynesian state \\
\hline $\begin{array}{l}\text { Compatible } \\
\text { orders of worth }\end{array}$ & Domestic order & $\begin{array}{c}\text { Industrial } \\
\text { order, } \\
\text { civic order, } \\
\text { domestic order }\end{array}$ & $\begin{array}{c}\text { Network } \\
\text { order, } \\
\text { industrial } \\
\text { order, } \\
\text { market order, } \\
\text { reputational } \\
\text { order }\end{array}$ & $\begin{array}{l}\text { Civic order, } \\
\text { industrial } \\
\text { order }\end{array}$ \\
\hline
\end{tabular}

As common points of reference, indicators used for the measurement of spatial disparities or the allocation of socio-material school infrastructure often represent a compromise between different orders of worth. Discretionary forms of quantification emerge from a domestic order of worth and exhibit a low standardization. Bureaucratic forms of quantification strive for increased efficiency in public administration but often limit benefits to certain (numerically defined) categories of citizens. Thus, they seem to represent a compromise between the industrial and the civic worlds, while (an implicit hierarchy of) categories might retain traces of a domestic order of worth. Epistemic forms of quantification in the form of education monitoring aim to highlight problems of the (local) education system and induce evidence-based cooperation among stakeholders, pointing to a compromise between a network and an industrial logic of coordination. Epistemic forms of quantification in the form of school league tables formally introduce market logic by substituting prestige for price signals. Calculative forms of quantification try to strike a balance between civic rights and industrial efficiency. However, as indicators claim to describe a part of the world, numerical representations can also become the source of tension, for example when the indicated phenomena change in a way that contradicts some normative expectations more than others.

The empirical part of this article will show that, in Germany, calculative forms of quantification have been institutionalized in school planning in order to contribute to spatial 
justice for all citizens and economic growth. Tensions arose soon after from unexpected declines in enrolments.

\section{Governing Spatial Disparities of School Infrastructure by Numbers in Germany \\ 3.1. Discretionary School Policy and Limited Investments in Quantification}

The idea of compulsory schooling was variously codified in the German states as early as the 17th century. Though codified, for example, in the Prussian Legal Code (Allgemeines Landrecht) of 1794, universal access to-at least elementary-schooling was not achieved until the period after the foundation of the Weimar Republic in 1919 [43] (p. 98). The role of quantification in this early period is rather limited because official statistics were only starting to become established and expansion was not driven by a "center of calculation" [21]. Instead, rather fragmented administrative structures emerged from the interplay of the ambivalent school policies of the German states and local governments, as well as an increasingly self-reinforcing dynamic of the education system itself at the end of the 19th century [52] (p. 483). As Prussia was the largest state (which would later form $65 \%$ of the territory of the German Empire), my analysis of the period before 1871 will focus on it.

3.1.1. Allocating School Infrastructure Resources through Discretionary and Bureaucratic Quantification

Schools in Prussia not only reflected deep class divides but also revealed marked spatial disparities. In 1816, participation rates in elementary schools varied between $22 \%$ of the school-aged population in the province of Poznan to 85\% in the province of Saxony [53] (p. 89). At the same time, elementary schools were clearly associated with rural areas, whereas advanced-track schools were associated with cities. The factual allocation of school resources to certain categories of place can thus be regarded as a discretionary form of quantification. In 1830, only two of the then 110 Gymnasien in Prussia were not located in a city [53] (p. 90). Although spatial disparities, especially rural-urban ones, were widely acknowledged, this was probably as much a result of subjective observations as it was the result of statistical ones. The lack of stable conventions of data collection, as well as the often arbitrary criteria for the allocation of resources, indicates that spatial disparities were only governed by numbers to a very limited extent in the 19th century. For example, while it was formally mandatory for children between 5 and 14 to attend school, this obligation was not only watered down by several exemption clauses, formal rules also allowed substantial leeway for administrative decision makers to determine the length of a pupil's school career using social status as a criterion. Instruction was supposed to continue "until a child has, in the judgement of a clergyman, achieved the requisite level of knowledge of a reasonable person of his social standing" [54] (p. 98). This case falls somewhere between discretionary and bureaucratic quantification: status categories determine the appropriate number of school years-as judged by a local authority.

In the field of education, the administrative power of the Prussian state developed fairly late compared to other policy fields [55] (p. 627). Initiatives to reform the Prussian school administration at the end of the 18th and the beginning of the 19th century were based on a categorization of school types that distinguished between elementary schools and advanced-track schools (Gymnasien). Intermediate-track schools (Mittelschulen or Bürgerschulen) emerged during the 19th century, forming a tripartite distinction which was to become formative for the German education system [56] (pp. 200-232). Towards the end of the 19th century, the Prussian state strove to limit access to advanced-track schools [57], which points to numerus clausus policies in the sense of bureaucratic quantification and strengthened the intermediate-track schools. However, it must be borne in mind that, for much of the 19th century, these categories simplified what was actually a plural and diverse reality of schools that coexisted rather than forming an actual school system. While elementary schools were meant to teach the population basic skills, advanced-track 
schools provided access to universities and the state civil service and exempted pupils from military service.

Reforms in the administration of education at the beginning of the 19th century contained centralizing as well as decentralizing elements [58]. Standardizing reform measures showed up most clearly in the creation of central authorities for education administration. However, their power to govern the field of education did not rest on a general school code; instead, the government regulated the field in a discretionary way through ubiquitous provisions that governed the details of schooling. After the revolution of 1848-1849, the refusal of the Prussian government to propose a school code was also a strategy to avoid political debates in the House of Representatives, the second chamber of the Prussian legislature [59]. On the local level, the City Code (Städteordnung) of 1808 granted the cities ample self-governing rights in matters pertaining to schools. The situation was different for rural municipalities because, for them, the Prussian Legal Code (Allgemeines Landrecht) still applied, which granted local landowners and clergymen substantial authority. In general, the most important rights and obligations of local actors were the appointment of teachers and school funding. The largely decentralized bodies responsible for staffing and financing schools made territorial standardization through quantified rules difficult; some argued that the Prussian state did not actually put much effort into it [59]. In 1849, only $0.47 \%$ of the central state budget was spent on elementary schools and $0.32 \%$ on advanced-track schools, whereas $29.17 \%$ was spent on the military [60] (p. 479).

The most important expansion steps were taken after the formation of the German Empire when the Schulaufsichtsgesetz of 1872 revoked the supervision of elementary schools from the church and formally gave this task to the central state. At the end of the 1880s, elementary schools increasingly became funded by the central state because poor municipalities had difficulties in adapting their schools to the pace of demographic growth, which gave the central state more influence. However, the education infrastructure policy of the central state was still largely dominated by discretionary decisions. This was the case for local authorities and was reflected in the lack of objective criteria for state subsidies to municipalities in need. Only the school finance law of 1906 (Volksschulunterhaltungsgesetz) and the teacher remuneration law of 1909 (Lehrerbesoldungsgesetz) created a unitary legal framework for central state funding which benefited small municipalities most [61] (pp. 556-558).

\subsubsection{Limited Investments in Measuring Spatial Disparities in Schooling}

What was the role of official statistics in the process of governing spatial disparities? The use of statistics for education purposes did not develop linearly, nor did it affect political and administrative decision making in a predictable way. The German states began producing education statistics during the 19th century, with indicators being far from standardized and data collection being interrupted at several stages in the different states [62].

In Prussia, the first periodical form of data collection and publication was not established until after the foundation of the Royal Statistical Bureau in 1805. Its director, Johann Gottfried Hoffmann, introduced a Church and School Table (Kirchen- und Schultabelle) in 1822 , which appeared every three years and contained information on elementary schools, teachers, and pupils [63] (p. 65). Statistics began being kept on advanced-track schools in 1830 and on intermediate schools in 1853 [64] (p. 266). Keeping these statistics at all indicates a potential administrative value; yet, keeping them separate from one another indicates that their subjects were regarded as essentially different, corresponding to a discretionary or bureaucratic form of quantification. Yet, the School Table was discontinued in 1864 because, according to Ernst Engel, then director of the Royal Statistical Bureau, it was insufficient for administrative as well as for scientific purposes [62] (p 16). Furthermore, the Ministry of Education (Ministerium der geistlichen, Unterrichts- und Medizinalangelegenheiten) had started collecting its own statistical data on elementary schools in 1859, which continued up to 1871. The Royal Statistical Bureau strove to introduce new school statistics 
that met international methodological standards [64]. A first attempt in 1867 failed, but in 1873 , after years of negotiation, the ministry of education finally agreed. However, the plan for conducting a school census, developed in 1877, was not implemented due to budgetary restrictions. After two extraordinary surveys mandated by the ministry of education in 1879 and 1882, as well as years of further consultation in the Central Statistical Commission (Statistische Central-Commission), the Royal Statistical Bureau was able to implement a general census of the so-called lower-track schools (Volksschulen, Mittelschulen) in 1886, which was repeated every five years until 1911 [62].

The 1880s can be considered a period when the constitution of periodical school statistics began taking off in all German states [63]. Since education statistics in the German Empire were under the jurisdiction of the federal states, statistical officers of the states needed to agree on a standard for school statistics in order to produce indicators for the whole Empire, which they did in 1901. In 1906, the Imperial Statistical Office (Kaiserliches Statistisches Amt) started coordinating data collection as well as compiling and publishing the results of a census of all elementary schools in the territory. Starting in 1911, the school census also included intermediate-track as well as advanced-track schools.

In order to understand the practical value of official statistics for measuring spatial disparities in schooling, it is necessary to analyze the content of the indicators produced. On the one hand, statisticians repeatedly pointed to overcrowded schools in places with rapidly increasing school-aged populations and poor municipalities [61] (p. 569). On the other hand, the value of official statistics for purposes of governing spatial disparities in schooling should also not be overestimated. In general, the practical value of school indicators was diminished because absolute numbers tended to be reported, which might have served bureaucratic purposes but made spatial comparisons difficult.

Contemporary scholars caution against taking the values reported in 19th century statistics in Prussia at face value [60] (p. 143). For example, even in Berlin, a reliable system of identifying pupils and their place of residence was not introduced until the late 1860s [60] (p. 140). Pupils in rural or industrial areas were often classified as "attending school", even though they missed lessons for weeks or months at a time because they were working in agriculture or manufacturing trades such as the textile industry. This is in part due to the fact that the school censuses were conducted in the winter when school attendance was higher than in the summer when children in rural areas were engaged in agricultural work [60] (p. 139).

For the analysis of how the Prussian state "saw" the territorial distribution of schools, I will focus on elementary schools, since advanced- and intermediate-track schools were primarily located in cities and towns. Furthermore, for pragmatic reasons, I will focus on a secondary analysis of historical time series that were constructed from original sources in a long-term research project, largely preserving the original categories while transforming absolute into relative numbers [43]. When reconstructing the establishment of statistics, breaks and innovations in the categories observed are of crucial importance [17] (p. 249). Secondary sources are well suited to highlighting some of these breaks. While statistics on the number of full-time teachers and the number of schools were collected from 1816 onwards, statistics about the distribution of elementary schools across urban and rural areas were not initiated until 1849 (Figure 2). This innovation in the information infrastructure of the Prussian state was introduced in a period when urbanization became a topic of current concern, which was also of interest to Karl Friedrich Dieterici, then director of the Royal Statistical Bureau. Although access to elementary schools gradually became universal in the late 19th century [43] (p. 98), Figure 2 shows that spatial disparities in equipping schools with teachers actually widened. The rural-urban gap displays some signs of consolidation after 1890, when the Prussian state began to take on some responsibilities in terms of school funding [61] (pp. 556-558). 


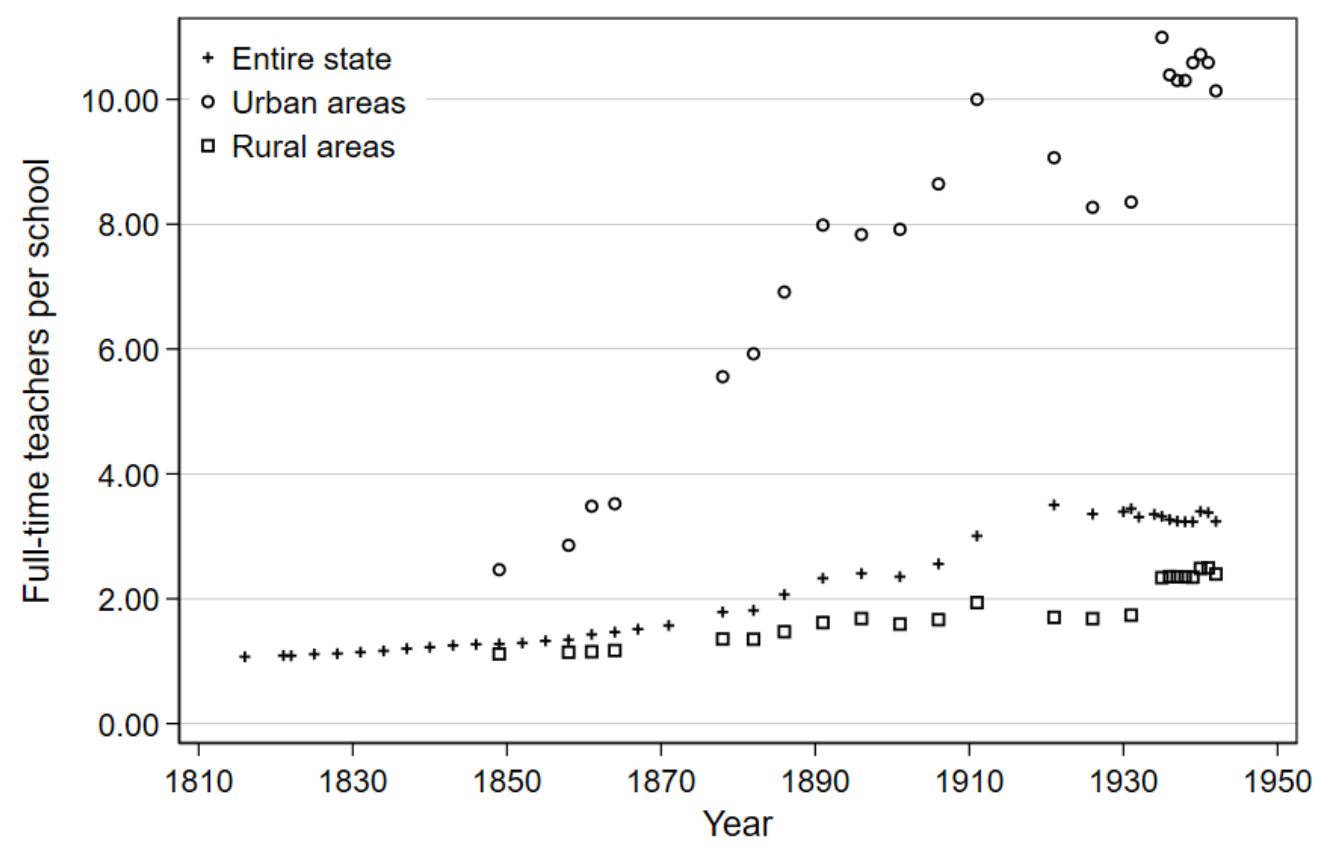

Figure 2. Number of full-time teachers per school in Prussia (1816-1942). Source: [43] (CD).

3.1.3. Little Instrumental Connection between Measuring Spatial Disparities and the Spatial Allocation of School Resources

Although official statistics provided a certain degree of informationabout spatial disparities in schooling, this information did not lead to spatially balanced legislation. A ministerial provision of 1872 (Allgemeine Bestimmungen), renewing a similar regulation of 1827 , stipulated that, in a one-room elementary school, no more than 80 children should be taught by one teacher; beyond 100 pupils the employment of a second teacher was required [65] (p. 4). However, Figure 2 shows that this provision had little effect on spatial disparities in schooling. When supervising authorities tried to oblige local governments to spend more on staffing or school buildings, the power of the central state quickly reached its limits. Since there were no objective criteria of municipal capability defined in legal regulations, investments in education infrastructure largely remained at the discretion of local governments [61] (p. 557). Even in cases where the central state stepped in and shouldered local education expenditures, towns with comparable tax revenues benefited from intergovernmental transfers to a surprisingly varying extent [61] (p. 569). We can conclude that even the monetized field of fiscal relations, which is today a typical example of calculative quantification, was still subject to discretionary quantification in the late 19th century.

Rather than being centrally governed in a substantial sense, the school policy of secondorder cities and towns tried to imitate the model of large cities. Even though by the end of the 19th century the national state administration began to demand projections of future enrolment, these were practically impossible due to the rather high internal migration rates, especially in newly industrializing regions [61] (p. 565).

The very few historical studies that give an insight into the possible use of indicators in processes of school administration or planning show that some indicators were present but actually of limited relevance. Documents on the reform of the upper tier of the school system which strove to reduce the number of schools in late 19th century Prussia do mention administrative indicators, such as enrollment; however, they were not codified in the sense of bureaucratic quantification and were of lesser importance than, for example, political considerations of decision making bodies [57]. In particular, there were no codified thresholds for school closures and no stable connections between the observation of spatial education needs and the allocation of schools typical for contemporary school planning procedures. 
In terms of the heuristic developed in the conceptual part of this article, before the Second World War, the governance of spatial disparities in school infrastructure was dominated by discretionary and implicit bureaucratic quantification. The latter is especially evident in the non-formalized numerus clausus policy for advanced-track schools. In conventionalist terms, the governance of the education system followed domestic logic much more than civic logic. Social status, derived from class, religious confession, and gender, but also spatial distinctions and corresponding social rights, dominated school policy rather than the idea of equal individual rights. Spatial infrastructure policies for elementary schools did not begin to become more standardized until the latter part of the 19 th century, with the advent of the welfare state [18].

\subsection{The Decentralized Institutionalization of Calculative Quantification in School Planning}

The analysis in this section will focus on West Germany after the Second World War because it is the institutional model of calculative quantification that prevailed after the German Reunification and has had significant, although ambivalent, consequences for the governance of spatial disparities in schooling by numbers [13-15]. Firstly, calculative school development planning was institutionalized relatively late compared to the actual developments in enrolment rates. Secondly, its institutionalization as a mechanism of calculative quantification in-kind did not take place on a national level but relied on numerical thresholds of organizational viability at the federal state level and the decentralized standardization of using numbers for professional planning practices. Thirdly, its institutionalization produced significant tensions, with normative expectations directed at the education infrastructure as a form of territorial welfare politics when enrolments declined.

\subsubsection{Investments in Centralized National Education Planning and Its Failure}

After the Second World War, the school systems of the West German federal states displayed significant territorial particularities in terms of the confessionalization or laicization of elementary schools, the co-education of genders, and the existence of intermediate-track secondary schools. Rural-urban differences were still significant. Even before the Federal Republic of Germany was founded in 1948, the federal states had created the Standing Conference of the Ministers of Education and Cultural Affairs of the Länder (Kultusministerkonferenz, KMK) in order to illustrate that they were able to cooperate horizontally and to fence off potential authority at the federal level in matters of education. In 1955, the federal states agreed on measures to standardize their legislation (Düsseldorfer Abkommen zur Vereinheitlichung des Schulwesens) in order to resolve some of the particularisms that were increasingly regarded as chaotic by the public. An important element was the codification of the tripartite school system [66] (p. 61). Separating pupils into different school tracks was legitimated by referring to a vocational order of the labor market that was regarded as fixed or by pointing to different talent types that were assumed to be natural [66] (p. 58).

Despite these moments of conservatism, the 1950s were also subject to incremental dynamics resulting from rapid economic growth and the influx of refugees [67] (p. 30). This, combined with small age cohorts entering the education system after the Second World War, led to regional shortages of skilled workers as well as a broader access to intermediate- and advanced-track secondary schools with socio-material overcapacities [67] (pp. 202-203). With respect to the subject of this article, it is important to note that enrolment rates in intermediate- and advanced-track secondary schools increased before any attempts at a systematic planning of the education system were made at a national level. As in the 19th century, educational expansion up until the mid-1960s was driven by local initiatives, which meant mainly discretionary quantification guided by domestic conventions. Although the school-aged population increased during the 1960s and early 1970s, the enrolment rate in intermediate- and advanced-track schools continued to grow, which arguably contributed to a leveling out of rural-urban disparities. So, how and why did the use of numbers in governing spatial disparities in schooling change in this period? 
In the 1960s, following the Sputnik crisis of 1957 and a wave of decolonization in the Global South, international organizations recommended that nation states take up education planning in order to foster economic development. The United Nations, for example, founded the International Institute for Educational Planning in 1963; by 1968, its directory of institutions involved in training and research on educational planning already listed 130 organizations in 36 countries [68]. In Germany, the activities of the Organization for Economic Cooperation and Development (OECD) had a considerable influence on political support for educational planning.

Spatial disparities in education were an integral part of the international endeavor to discover "untapped reserves of ability" [69] (p. 69). In Germany, the discourse around a possible reform of rural schools picked up in the 1950s [70], calling into question the idea of rural and urban areas being worlds apart, which had been taken for granted throughout the 19th century. However, in West Germany, the term educational planning was not used widely in this discourse until the 1960s. When it did appear, it carried with it the notion of using indicators for (relatively) long-term planning [71]. The diverse bodies that were created in order to coordinate education policies between the central and the federal state levels involved scientific experts but only used indicators to a limited extent. The first of these bodies, the German Committee for Training and Education (Deutscher Ausschuss für das Erziehungs- und Bildungswesen) (1953-1965), developed a total of 30 policy papers for the reform of the education system. Most of these recommendations, however, lacked not only empirical scientific evidence but also the most simple descriptive statistics on the education system [67] (p. 103).

In 1962, the first planning exercise by an official authority was undertaken by the horizonal cooperation body of the federal states in cultural matters: the KMK [72]. Explicitly mentioning the international discourse of the OECD on the education system and economic growth, the KMK projection strove to estimate the future demand for schools and universities on which to base staffing and personnel requirements in the coming decade [67] (p. 127). These projections were politicized in the public discussion as an "educational catastrophe" mounting to claims for "education as a civil right" [66]. The federal states not only developed a common model for future projections, but by 1970, they had also created planning departments and conducted projections for their own jurisdictions. In this respect, the KMK projection served as a template for formulating explicit numerical targets of expansion. In 1964, the KMK listed the improvement of school infrastructure as one priority of educational policies. Furthermore, during this period, evidence about spatial inequalities was repeatedly the subject of individual scientific studies [2]. While a more general optimism towards educational research and planning took shape, the number of organizations in that field in Germany increased from four (1963) to 25 (1972) at the peak of the educational expansion [67] (p. 164). At the same time, there was an increased demand for, and dissatisfaction with, the education indicators available through official statistics at the federal level [46].

As a successor to the German Committee for Training and Education, the national government and the federal states founded the German Educational Council (Deutscher Bildungsrat), which consisted of a political and an educational commission and operated for two terms (1965-1970; 1970-1974). Two aspects of the work of the German Educational Council are important in terms of governing spatial disparities in education by numbers. First, it substantially challenged the assumption of natural talent which legitimated the need for the early tracking of students in the German school system. Instead, learning was seen as reflexive (pupils can learn how to learn). This resulted in the recommendation to experiment with the introduction of comprehensive schools. In addition, the German Educational Council focused its work almost exclusively on reform initiatives and largely refrained from actual planning. For this reason, the states and the federal government founded a separate Federation-States Commission for Educational Planning and Research Funding (Bund-Länder-Kommission für Bildungsplanung und Forschungsförderung), which was only made up of political and administrative members. It was meant to quantify not only 
the political aims but also the budgets that were required for implementation according to the policies. In 1973, it issued a plan for the entire education system (Bildungsgesamtplan), containing projections up to the year 1985 [73]. Although aspirations for macroeconomic manpower planning failed at the national level [66] (p. 72), the quantitative targets of these projections became the political basis for practical manuals on school planning [74] (p. 68), catering for the professionalization needs of local public administrations.

\subsubsection{Decentralized School Planning as a Calculative Governance Device}

In the late 1960s, federal state administrations and local governments were still debating on who would be responsible for school planning. Although the federal state education ministries had begun to create planning departments, these entities soon proved to be ill-suited for school planning because they were too detached from local conditions. Initial efforts for school planning were made in 1964 in a cooperation between the city-state of Hamburg and Schleswig-Holstein. Baden-Wurttemberg and Bavaria followed suit in 1966 with school plans issued at the state level. The first school plans on a local level were developed in the city of Wattenscheid (1965) and in the county of Wesermarsch (1966) [75]. A content analysis of the 62 school development plans, drawn up between 1966 and 1973, before the national Bildungsgesamtplan was issued, found that around $35 \%$ of them explicitly addressed the problem of spatial disparities in schooling. However, rather than specifying measures for compensating deficits in infrastructure supply, the plans mostly aimed at reforming the local school structure (e.g., by introducing an orientation phase at the beginning of the first stage of secondary school) [75] (p. 48). The authors of the study concluded that most of the plans displayed significant methodological deficits in terms of projecting enrolment figures by school type and age group on a sufficiently fine-grained spatial scale [75] (p. 59).

Orientation for local planners was provided by administrative "rules of thumb" for calculating school infrastructure in-kind that were, in part, formulated by academic scholars working towards reforming public administration in a more rational way. An influential book by Frido Wagener, first published in 1969, is telling in both the provision of quantitative rules of thumb for school planning as well as in justifying them. The author, a former practitioner, was concerned with finding the optimal size of administrative units in general. After an exhaustive review of national and international reform plans, he identified 22 criteria for justifying reforms which, according to him, could be narrowed down to two incommensurable groups of arguments: technical ones (economic efficiency and functional effectivity) and political ones (stabilizing democracy and maintaining the rule of law) [76] (pp. 284-314). However, while some measures might prove to be hard to quantify, in other cases he saw the possibility of bridging the fundamental contradiction between technical and political arguments through quantification. One prominent example was the quantitative definition of school catchment areas. Drawing on existing school legislation, demographic projections, and economic as well as pedagogical works on the rational administration of schools, he formulated recommendations on school organization and optimal catchment areas. These are summarized in Table 2 by school type. Standardizing class sizes, school sizes, and catchment areas was especially relevant for planning and constructing school buildings.

Table 2. Administrative indicators of school organization as recommended in 1969 [76] (pp. 339-348).

\begin{tabular}{ccccc}
\hline School Type & Classes & $\begin{array}{c}\text { Class Size } \\
\text { (Pupils) }\end{array}$ & $\begin{array}{c}\text { Optimal School Size } \\
\text { (Pupils) }\end{array}$ & $\begin{array}{c}\text { Population of } \\
\text { Catchment Area }\end{array}$ \\
\hline Primary school & 4 & 35 & 140 & $>2000$ \\
\hline Basic-track school & 15 & 35 & 525 & $>13,500$ \\
\hline Intermediate-track schools & $18-36$ & 30 & $540-1080$ & $35,000-70,000$ \\
\hline $\begin{array}{c}\text { Advanced-track } \\
\text { schools }\end{array}$ & 27 & $25-30$ & 735 & $37,000-75,000$ \\
\hline
\end{tabular}


In the 1970s, school planning had mainly become the responsibility of local districts, with states taking on a supervisory role [77] and [78] pp. 14-108. Practical manuals for school development planning began to be published around 1970 by a variety of actors: pedagogical journals in response to requests by local government officials [79], local government associations $[80,81]$, newly founded organizations, such as the Institute for School Construction of the States (Schulbauinstitut der Länder) [82], and academic scholars [74]. Although the legally codified idea of spatial planning ("unitary living conditions" across the nation) did not become a constitutive slogan in the area of school planning, expert discussions picked up on problems of school planning in rural areas or at a regional level $[77,83]$. A crucial element of manuals was the definition of relevant indicators and how to use them to calculate schooling capacities in-kind. Refining the scheme of Wagner's approach (Table 2), a manual on planning the consecutive stages of schooling focused not on the catchment areas of individual schools but on those of single streams within a school, projecting these over ten years [74]. It also paid attention to the typical enrolment rates of relevant age groups and their share in the total population, as well as the actual class sizes legitimated by the supervising federal state authority. The formula developed for calculating these indicators represented space from an organizational perspective, in other words the total population required in the catchment area. Beyond the representation of space in terms of population, the formula also introduced dynamism into the relation between the indicators. The static rules of thumb became variable.

The resulting plans had to incorporate a compromise between the actor groups' potentially diverging values attributed to schools. Although observers of that period identified a major political consensus on improving civic educational justice [84], state policies on secondary school structures fundamentally differed between federal states governed by conservative parties and those governed by the Social Democratic Party (SPD). Conservative parties favored the traditional tripartite tracking model, whereas the SPD supported an entirely new comprehensive school model. Indeed, it was possible that policies at the federal state level contradicted the strategy of local governments because the latter are typically less influenced by party ideologies than those at the state level. For small localities, it might be more important to have a local school at all (domestic order) than to have a specific type of one (civic order). In turn, planning professionals tended to define school development planning more narrowly as a compromise between pedagogical and economic aims [85]. With regard to school size, it has been argued that two reasons speak in favor of larger schools: first, a modern society requires a minimum degree of differentiation in the subjects taught, and second, larger schools are economically more efficient [77]. Both arguments represent an industrial order of worth. As a result of these diverging arguments, federal states defined minimum and maximum thresholds of viability for each school type.

A common critique directed against school planning as a calculative governance device has been that, since there were actual demographic data and legitimate administrative thresholds, local autonomy was curtailed to a maximum degree. Although local governments were given the responsibility for school planning, federal states still had substantial competencies in classifying localities eligible for certain types of schools within the System of Central Locations that has structured spatial planning since the 1960s [86]. Furthermore, federal state authorities supervised local school planning not only in a legal but also in a functional sense [87] (pp. 105-106). Without the approval of the state, local school plans were not viable because the federal states were (and still are) responsible for employing teachers. As a consequence of the school reforms in the 1960s and the increasingly professional activities of school planning, the average organizational size of school types increased [77].

After the German Reunification in 1990, the same calculative planning standards and procedures were basically translated to the eastern federal states [88]. 


\subsubsection{Tensions and Compromises}

The decentralized institutionalization of relatively standardized school planning procedures based on key indicators had both intended and unintended consequences. Although elementary schools had been reformed in 1964 to consist of two cycles (primary school and basic-track school at the secondary level), heterogeneous organizational relations often remained, depending on the federal state. Therefore, in federal statistics, the two cycles were not separated until 1986. A rather immediate consequence of the elementary school reform and the ensuing school planning was that school size increased. Especially in rural areas, small schools were consolidated in order to achieve higher internal differentiation, which led to a need for larger buildings and a significant wave of school closures (Figure 3, left panel). During the 1960s and early 1970s, these closures did not lead to major political tensions because they seemed to be justified by achieving a higher quality of school infrastructure. A case study argues that closures of rural elementary schools were based largely on federal state-local negotiations rather than abstract quantitative criteria, which were still in an incipient phase of institutionalization [89]. Plus, at the same time as these closures, there was an expansion of intermediate-track and advanced-track schools (Figure 3, right panel), which was increasingly guided by professionalized decentral planning procedures.

Structural tensions in the school system, attributable to the use of numbers in planning procedures, emerged from the mid-1970s onwards. The economic downturn put pressure on public budgets while, at the same time, the decline in births reached the school system, leading to falling student numbers [90]. While some welcomed smaller cohorts as an opportunity to improve the quality of teaching, actual enrolment increasingly contradicted the formally codified requirements of the federal state laws on viable schools. During the late 1970s and 1980s, the emerging tension was typically resolved at the federal state level by lowering minimum thresholds of organizational viability in order to assure a locally accessible school infrastructure [91]. Closing schools was seen as contradicting equal rights across the nation [92]. At the same time, unitary administrative standards of class frequencies for rural and urban areas were also seen as symbols of civic spatial justice. In Bavaria, lower class frequency standards for rural areas were challenged by parents from the federal state capital in lawsuits against the state [93] — a pattern of civil protest against discretionary quantification that was again observed in the 2010s in East Germany $[13,14]$. Primary schools, intermediate-track, and advanced-track schools profited most from the stabilization by federal state policies. Basic-track schools in turn were closed more often, not only for demographic reasons but also due to a lack of social demand. Unlike every other school type, the number of basic-track schools has declined continuously since records on it began being kept separately in federal statistics in 1986 (Figure 3, right panel).

In the late 1970s, declining enrolments and the resulting tensions sparked academic research that began to question the pedagogically negative image of small schools and age-integrative classes [94]. Some states explicitly developed policies to reintroduce small rural schools, especially at the primary level, in order to avoid long commuting times to schools [95]. Yet, the model of small schools (domestic logic) remains under significant pressure by arguments of efficiency (industrial logic) [96], which is reflected in the decline in the number of primary schools since the second half of the 2000s (Figure 3, left panel). A rather new phenomenon and a potential compromise between domestic and industrial logics is "schools with more than one school track", an organizational form that seems to be more suitable for providing secondary school infrastructure in rural areas than the traditional tripartite organizational model. 


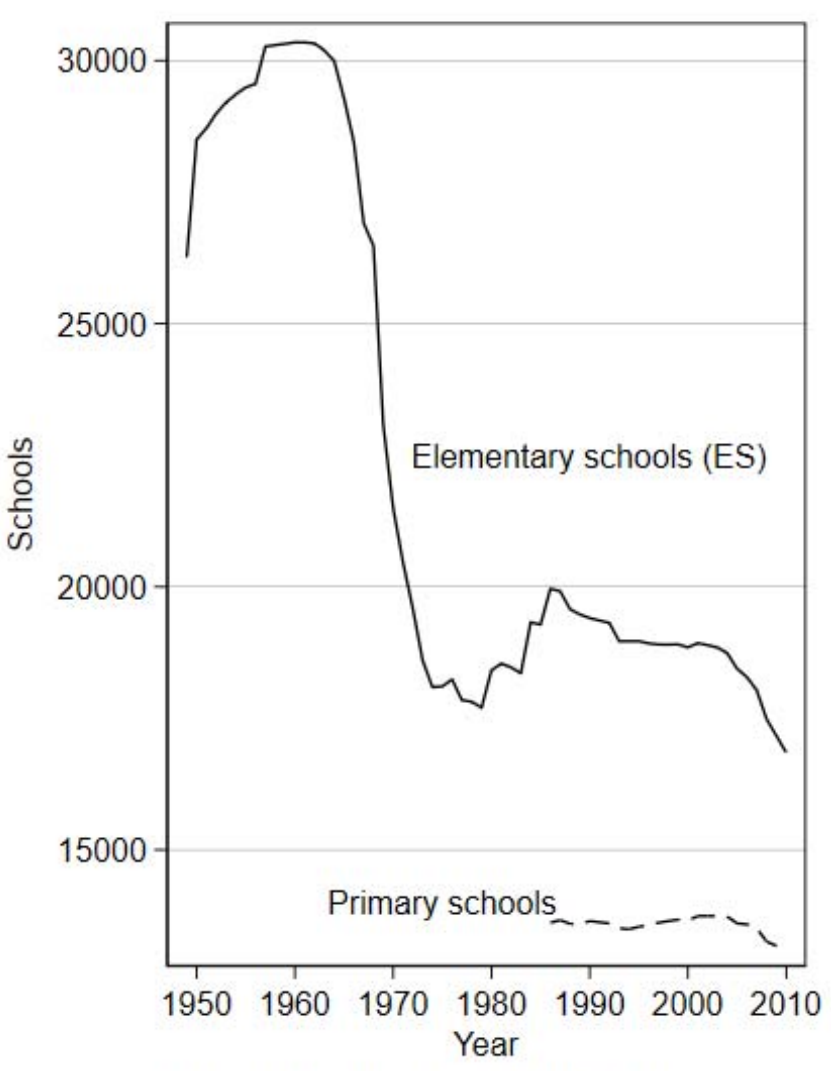

After 1986: ES $=$ Basic-track schools + Primary schools

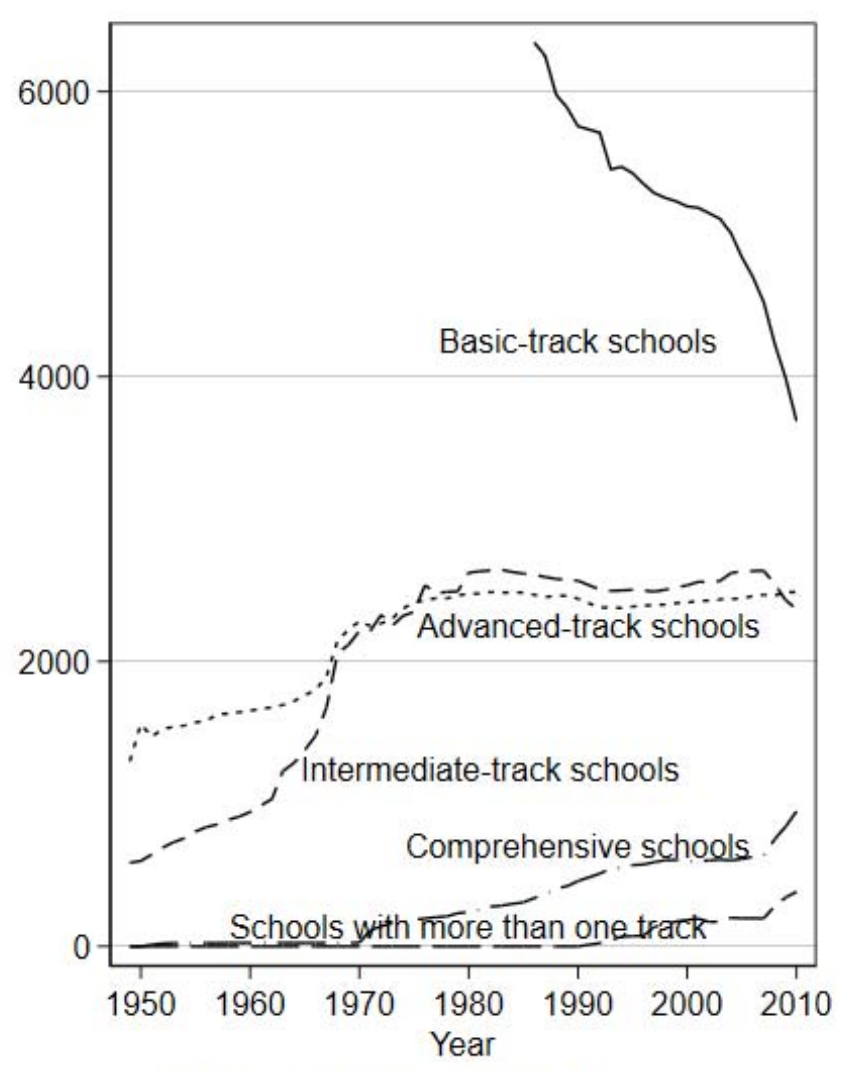

Comprehensive schools contain Waldorf schools

Figure 3. Schools by school type in West German states (1949-2010). Source: [97].

\section{Discussion}

Taking a broad institutionalist perspective, this article has built upon crucial contributions to the emerging field of Quantification Studies as well as Economics of Convention in order to analyze the historical change of how spatial disparities have been governed by numbers in Germany. Of analytical importance has been the distinction between using indicators for more or less standardized information gathering, which typically implies an evaluation of the information, and using indicators for allocating resources or liabilities in a more or less formalized way. Crossing these two dimensions of using indicators for decision making results in four ideal types of governing spatial disparities in school infrastructure by numbers.

Empirically, I showed that despite compulsory schooling having been codified in Prussia as early as the 18th century, spatial disparities prevented it from being achieved until the early 20th century. While investments in the production and use of indicators took place during this period, school infrastructure was mainly governed by discretionary and bureaucratic forms of quantification that very often failed to adapt infrastructure to the education needs resulting from demographic growth or to level out rural-urban disparities in the quality of schooling. In fact, rural and urban areas were seen as being worlds apart in school matters. This did not change substantially until after the Second World War. Until the late 1960s, reductions of spatial disparities in enrolment rates in schools were driven by rather heterogeneous local processes and involved relatively little systematic use of indicators, corresponding largely to a discretionary quantification and domestic logic. How and why did that change?

In the late 1960s and early 1970s, the governance of spatial disparities in school infrastructure changed gradually from a discretionary to a calculative form of quantification. Beginning in the 1960s, following an agenda set by international organizations and translated into public critique, several investments were made to institutionalize educational 
planning at the national level, which failed in the end. This was primarily due to the politicization of educational matters at the federal state level between conservative parties and the Social Democratic Party, who interpreted the growing consensus on a civic right to education differently with regard to school infrastructure policy. Nevertheless, the increasing cultural urbanization of rural areas through mobility and national mass media had contributed to the creation of comparable expectations towards the school infrastructure in rural and urban areas. With school planning being formally assigned to the local level and more academically educated actors defining the terms of a professional administrative practice based on the calculative use of numbers, this practice became institutionalized, which has been crucial for the governance of spatial disparities in school infrastructure. The standardization of calculative school planning was effectuated on the one hand by the political definition of legitimate numerical thresholds of school viability and corresponding procedures at the federal state level. On the other hand, key indicators and formulas for calculating school capacities in-kind (i.e., school-size indicators and demographic indicators) were defined by an increasingly professionalizing community of scholars and practitioners, objectifying their knowledge in scientific discourse, practical manuals, and study programs. During the formative period of school planning as a governance device, the key indicators of this device became imbued with meanings from different orders of worth, most importantly they took on civic and industrial meanings, i.e., justice for all citizens and efficiency [36]. This seems to differ from the French case, where-in the period before the 1980s-mainly civic justifications were relevant to schools [37]. The domestic order of worth, which is typically important for local actors, was marginalized to a certain extent, especially in the 1970s.

As a result of decentral standardized school planning, the grade differentiation of rural elementary schools has increased and new secondary schools beyond the basic-track level have been created. However, as black box entities, key indicators of school planning also triggered a critical hiatus between political claims for equivalent living conditions and the efficiency of school organization when enrolment began to drop off for demographic reasons and due to a dwindling demand for basic-track schools. Despite various forms of amelioration of political conflicts between federal state and local governments and some innovations in school organization, the calculative logic of school planning has largely remained in place.

While the current demographic situation does not seem to contribute to further tensions with administrative thresholds of school planning, projections for the upcoming years indicate that there will very likely be similar tensions and hence recurring questions of civic spatial justice, especially at the secondary school level.

Epistemic forms of governance have yet to play a major role in governing spatial disparities in Germany. While spatial disparities have started to be reported mainly on a federal state level in the National Report on Education, school infrastructure at the more relevant district level has undergone little assessment in this highly visible report. Evidence on sustained spatial disparities has often been produced by individual empirical studies. One conclusion from such evidence has been to demand compensatory allocation mechanisms for education institutions in challenged areas. In the meantime, calculative resource allocation based on social indices has been implemented in most federal states [49]. Yet, compensatory resource allocation based on formalized quantification runs the risk of also stigmatizing the beneficiary organizations. Furthermore, these practices are not standardized across the nation and typically affect only a small part of the overall resources. Therefore, more research is needed on how these new instruments of governing spatial disparities by numbers in a calculative way actually affect educational processes and educational outcomes.

Funding: I acknowledge the financial support within the funding programme Open Access Publishing by the German Research Foundation (DFG).

Institutional Review Board Statement: Not applicable. 
Informed Consent Statement: Not applicable.

Data Availability Statement: The data analyzed in this article is publicly available as indicated in the sources 43,76 and 97.

Acknowledgments: I am grateful for the comments of colleagues at Martin Luther University HalleWittenberg on an earlier version of this article, in particular from Reinhold Sackmann, Manfred Stock, Katarzyna Kopycka, Oliver Winkler, and Fabian Schmid. I also appreciate - in the best sense-the critical reading of this article by three anonymous reviewers as well as by the guest editors of this special issue. I am also grateful to Lorri King, who took care of the copy editing.

Conflicts of Interest: The author declares no conflict of interest.

\section{References}

1. Heidenreich, M. Regionale Muster von Bildungsarmut. In Handbuch Bildungsarmut; Quenzel, G., Hurrelmann, K., Eds.; Springer: Wiesbaden, Germany, 2019; pp. 29-38, ISBN 978-3-658-19572-4.

2. Sixt, M.; Rossen, A.; Fuchs, S. Immer noch Bildungsnotstandsgebiete? In Handbuch Bildungsarmut; Quenzel, G., Hurrelmann, K., Eds.; Springer: Wiesbaden, Germany, 2019; pp. 121-155, ISBN 978-3-658-19572-4.

3. Löw, M. In Welchen Räumen Leben Wir? Eine Raumsoziologisch Und Kommunikativ Konstruktivistische Bestimmung Der Raumfiguren Territorialraum, Bahnenraum, Netzwerkraum Und Ort. In Grenzen der Kommunikation-Kommunikation an den Grenzen; Reichertz, J., Eickhoff, J., Eds.; Velbrück Wissenschaft: Weilerswist, Germany, 2020; pp. 149-164, ISBN 3-95832-199-2.

4. Seitzer, H.; Besche-Truthe, F.; Windzio, M. Networks of Global Policy Diffusion: The Introduction of Compulsory Education. In Networks and Geographies of Global Social Policy Diffusion: Culture, Economy, and Colonial Legacies; Windzio, M., Mossig, I., Besche-Truthe, F., Seitzer, H., Eds.; Springer: Berlin/Heidelberg, Germany, 2022; pp. 59-81, ISBN 978-3-030-83403-6.

5. Meyer, J.W.; Rubinson, R. Education and Political Development. Rev. Res. Educ. 1975, 3, 134-162.

6. Normand, R. The Changing Epistemic Governance of European Education: The Fabrication of The Homo Academicus Europeanus? Springer: Berlin/Heidelberg, Germany, 2016, ISBN 978-3-319-31774-8.

7. Bildungsberichterstattung, A. Bildung in Deutschland 2018: Ein Indikatorengestützter Bericht Mit Einer Analyse zu Wirkungen und Erträgen von Bildung; wbv: Bielefeld, Germany, 2018.

8. Brüggemann, C. Datenbasiertes Bildungsmanagement als Steuerungsversprechen der Regionalisierungspolitik im Bildungswesen. Z. Für Pädagogik 2021, 67, 338-352.

9. van Dooren, W.; Bouckaert, G.; Halligan, J. Non-use. Performance Management in The Public Sector, 2nd ed.; Routledge: London, UK, 2015; pp. 154-173.

10. Hartong, S.; Förschler, A. Opening the black box of data-based school monitoring: Data infrastructures, flows and practices in state education agencies. Big Data Soc. 2019, 6, 1-12. [CrossRef]

11. Caven, M. Quantification, Inequality, and the Contestation of School Closures in Philadelphia. Sociol. Educ. 2018, 37, 21-40. [CrossRef]

12. Ares Abalde, M. School Size Policies: A Literature Review; OECD Education Working Papers No. 106; OECD Education: Paris, France, 2014.

13. Bartl, W.; Sackmann, R. Governance Indicators and Responsiveness to Population Decline: School Closure as Practice and Discourse in Saxony-Anhalt. Comp. Popul. Stud. 2016, 41, 321-358. [CrossRef]

14. Walde, A. Schulpolitik in Städten mit Schülerrü̈kgang. Eine Governance-Analyse am Beispiel von Leipzig und Timişoara; Springer: Wiesbaden, Germany, 2019.

15. Kann, C. Schulschließungen und Umbau von Schulstandorten: Steuerungsansätze bei sinkenden Schülerzahlen und die Rolle der Privatschulen; Springer: Wiesbaden, Germany, 2017.

16. Lehtonen, M. Indicators: Tools for Informing, Monitoring or Controlling? In The Tools of Policy Formulation; Jordan, A., Turnpenny, J., Eds.; Elgar: Cheltenham, UK, 2015; pp. 76-99, ISBN 9781783477043.

17. Desrosières, A. The Politics of Large Numbers: A History of Statistical Reasoning; Harvard University Press: Cambridge, MA, USA, 1998, ISBN 0-674-68932-1.

18. Desrosières, A. Words and Numbers. For a Sociology of the Statistical Argument. In The Mutual Construction of Statistics and Society; Sætnan, A.R., Lomell, H.M., Hammer, S., Eds.; Routledge: New York, NY, USA, 2011; pp. 41-63, ISBN 0-415-87370-3.

19. Thévenot, L. Rules and implements: Investment in forms. Soc. Sci. Inf. 1984, 23, 1-45. [CrossRef]

20. Thévenot, L. Measure for Measure: Politics of Quantifying Individuals to Govern Them. Hist. Soc. Res. 2019, 44, 44-76. [CrossRef]

21. Latour, B. Science in Action: How to Follow Scientists and Engineers Through Society; Harvard University Press: Cambridge, MA, USA, 1987, ISBN 9780674792913.

22. Heintz, B. Zahlen, Wissen, Objektivität: Wissenschaftssoziologische Perspektiven. In Zahlenwerk. Kalkulation, Organisation, Gesellschaft; Mennicken, A., Vollmer, H., Eds.; VS Verlag für Sozialwissenschaften: Wiesbaden, Germany, 2007; pp. 65-86.

23. Bartl, W.; Papilloud, C.; Terracher-Lipinski, A. Governing by Numbers: Key Indicators and the Politics of Expectations. An Introduction. Hist. Soc. Res. 2019, 44, 7-43. [CrossRef] 
24. Porter, T.M. Trust in Numbers: The Pursuit of Objectivity in Science and Public Life; Princeton University Press: Princeton, NJ, USA, 1995, ISBN1 0-691-02908-3 0-691-03776-0.

25. Espeland, W.N. Authority by the numbers: Porter on quantification, discretion, and the legitimation of expertise. Law Soc Inq 1997, 22, 1107-1133. [CrossRef]

26. Espeland, W.; Stevens, M.L. Commensuration as a Social Process. Annu. Rev. Sociol. 1998, 24, 313-343. [CrossRef]

27. Rose, N.S. Numbers. Powers of Freedom. Reframing Political Thought; Cambridge University Press: Cambridge, UK, 1999; pp. 197-232, ISBN 9780521659055.

28. Waibel, D.; Peetz, T.; Meier, F. Valuation Constellations. Valuat. Stud. 2021, 8, 33-66. [CrossRef]

29. Starr, P. The Sociology of Official Statistics. In The politics of numbers; Alonso, W., Starr, P., Eds.; Russell Sage Foundation: New York, NY, USA, 1987; pp. 7-57, ISBN 0-87154-015-0.

30. Emigh, R.J. Numeracy or Enumeration? The Uses of Numbers by States and Societies. Soc. Sci. Hist. 2002, 26, 653-698. [CrossRef]

31. Bruno, I.; Didier, E.; Vitale, T. Statactivism. Forms of action between disclosure and affirmation. Partecip. E Confl. 2014, 4, 198-220.

32. Christmann, G.B. Kommunikative Raumkonstruktionen als (Proto-)Governance. In Governance und Raum; Kilper, H., Ed.; Nomos: Baden-Baden, Germany, 2010; pp. 27-48, ISBN 978-3-8452-2625-5.

33. Barlösius, E. Infrastrukturen als soziale Ordnungsdienste: Ein Beitrag zur Gesellschaftsdiagnose; Campus: Frankfurt (Main), Germany, 2019, ISBN 3593510898.

34. Mann, M. The autonomous power of the state: Its origins, mechanisms and results. Eur. J. Sociol. 1984, 25, 185-213. [CrossRef]

35. Thévenot, L. Organized Complexity: Conventions of Coordination and the Composition of Economic Arrangements. Eur. J. Soc. Theory 2001, 4, 405-425. [CrossRef]

36. Boltanski, L.; Thévenot, L. On Justification: Economies of Worth; Princeton University Press: Princeton, NJ, USA, 2006. ISBN 9780691125169.

37. Derouet, J.-L. Lower Secondary Education in France: From Uniformity to Institutional Autonomy. Eur. J. Educ. 1991, 26, 119-132. [CrossRef]

38. Leemann, R.J.; Imdorf, C. Das Potenzial der Soziologie der Konventionen für die Bildungsforschung. In Bildung und Konventionen: Die „Economie des Conventions" in der Bildungsforschung; Imdorf, C., Leemann, R.J., Gonon, P., Eds.; Springer: Wiesbaden, Germany, 2019; pp. 3-45, ISBN 978-3-658-23301-3.

39. Boltanski, L.; Chiapello, E. The New Spirit of Capitalism; Verso: New York, NY, USA, 2007.

40. Sackmann, R. Mechanismen der Elitebildung: Theoretisches Konzept und empirische Trends im deutschen Bildungssystem und im internationalen Vergleich. Z. Für Pädagogik 2019, 65, 41-60.

41. Barton, A. The Concept of Property-Space in Social Research. In The Language of Social Research, 2nd ed.; Lazarsfeld, P.F., Rosenberg, M., Eds.; The Free Press: New York, NY, USA, 1957; pp. 40-53.

42. Helbig, M.; Nikolai, R. Die Unvergleichbaren. Der Wandel der Schulsysteme in den deutschen Bundesländern seit 1949; Klinkhardt: Bad Heilbrunn, Germany, 2015

43. Nath, A.; Titze, H.; Dartenne, C.M.; Kasel, G.; Oelerich-Sprung, C.; Schmeitzner, K.; Wloch, H.; Griebel, A.; Kneisler, T.; Kirste, I. Differenzierung und Integration der niederen Schulen in Deutschland 1800-1945; Vandenhoeck \& Ruprecht: Göttingen, Germany, 2016, ISBN 978-3-525-36213-6.

44. Dupuy, C. Converging Regional Education Policy in France and Germany; Palgrave: Cham, Germany, 2020.

45. Malan, T. Educational Planning as a Social Process; No. 33; Fundamentals of Educational Planning: Paris, France, 1987.

46. Köhler, H. Amtliche Bildungsstatistik im Wandel. In Gegenwärtige Probleme; Bildungsbericht, P., Ed.; Rowohlt: Reinbek bei Hamburg, Germany, 1980; pp. 1215-1285, ISBN 3-499-17338-7.

47. Barlösius, E. Die Macht der Repräsentation: Common Sense über Soziale Ungleichheiten; VS Verlag für Sozialwissenschaften: Wiesbaden, Germany, 2005, ISBN 978-3-531-14640-9.

48. Ringel, L.; Werron, T. Serielle Vergleiche: Zum Unterschied, den Wiederholung macht. Köln Z Soziol 2021, 73, 301-331. [CrossRef]

49. Klemm, K.; Kneuper, D. Zur Orientierung von Schulausgaben an Sozialindizes-Ein Bundesländervergleich. Available online: http:/ / library.fes.de/pdf-files/studienfoerderung/15755.pdf (accessed on 25 February 2022).

50. Bartl, W. Why do Municipalities 'Think' in Demographic Terms? Governing by Population Numbers in Germany and Poland. Coping with Demographic Change. A Comparative View on Education and Local Government in Germany and Poland; Springer: Dordrecht, The Netherlands, 2015; pp. 67-94, ISBN 9783319103013.

51. Prenzel, P.V. Regional Consequences of Demographic Change: Regional Development and Disparities in a Context of Ageing and Shrinking Population in Germany. Ph.D. Thesis, London School of Economics and Political Science, London, UK, 2017.

52. Wehler, H.U. Von der Reformära bis zur industriellen und politischen "Deutschen Doppelrevolution" 1815-1845/49; Beck: München, Germany, 2008, ISBN 340632262X.

53. Matzerath, H. Urbanisierung in Preußen 1815-1914; Kohlhammer: Stuttgart, Germany, 1985.

54. Budde, G. From the 'Zwergschule' (One-Room Schoolhouse) to the Comprehensive School: German Elementary Schools in Imperial Germany and the Weimar Republic, 1870-1930. In Mass Education and the Limits of State Building, c.1870-1930; Brockliss, L., Sheldon, N., Eds.; Palgrave: London, UK, 2012; pp. 95-116, ISBN 978-0-230-37021-0.

55. Neugebauer, W. Absolutistischer Staat und Schulwirklichkeit in Brandenburg-Preußen; de Gruyter: Berlin, Germany, 1985. ISBN 3110099209. 
56. Heinemann, M. Schule im Vorfeld der Verwaltung. Die Entwicklung der preußischen Unterrichtsverwaltung von 1771-1800; Vandenhoeck \& Ruprecht: Göttingen, Germany, 1974.

57. Herrmann, U.G. Schulplanung und Schulentwicklung in den Provinzen des Staates Preußen, 1890-1914. Regionale Differenzierung und gesamtstaatliche Systembildung: Preußen und seine Provinzen-Deutsches Reich und seine Staaten. 1800-1945; Vandenhoeck \& Ruprecht: Göttingen, Germany, 2003; pp. 75-159, ISBN 3-525-36212-9.

58. Rademacher, B. Zentralisierung und Dezentralisierung: Zur Genese der Schulverwaltung in der Konstitutionsphase der Bürgerlichen Gesellschaft, Dargestellt am Beispiel Preußens; Klinkhardt: Bad Heilbrunn, Germany, 1978, ISBN 3-7815-0382-8.

59. Roeder, P.M. Gemeindeschule in Staatshand: Zur Schulpolitik des Preußischen Abgeordnetenhauses. Z. Für Pädagogik 1966, 12, 539-569.

60. Leschinsky, A.; Roeder, P.M. Schule im Historischen Prozeß: Zum Wechselverhältnis von Institutioneller Erziehung und Gesellschaftlicher Entwicklung; Klett: Stuttgart, Germany, 1976, ISBN 3-12-926970-3.

61. Klewitz, M. Preußische Volksschule vor 1914. Zur regionalen Auswertung der Schulstatistik. Z. Für Pädagogik 1981, 27, 551-573.

62. Tredup, A.E. Statistik des deutschen Schulwesens: Historisch methodologische Untersuchung der Schulstatistik in den 5 grösseren Bundesstaaten seit Reichsgründung und der Reichsschulstatistik. All. Stat. Arch. 1923, 14, 1-81.

63. Titze, H. Historische Bildungsstatistik 1800 bis 1945. In Historische Statistik in der Bundesrepublik Deutschland; Statistisches Bundesamt: Wiesbaden, Germany, 1990; pp. 65-89.

64. Ficker, A. Schulstatistik. In Schule-Sophisten der Römischen Kaiserzeit; Schmid, K.A., Ed.; Besser: Gotha, Germany, 1870; pp. 243-281.

65. Der Minister der Geistlichen, Unterrichts- und Medizinalangelegenheiten. Allgemeine Bestimmungen über das Preußische Volksschul-, Präparanden- und Seminar-Wesen vom 15. Oktober 1872, 9th ed.; Heuser: Neuwied, Germany, 1887.

66. Lenhardt, G.; Stock, M. Bildung, Bürger, Arbeitskraft: Schulentwicklung und Sozialstruktur in der BRD und der DDR.; Suhrkamp: Frankfurt (Main), Germany, 1997, ISBN 978-3-518-28921-1.

67. Hüfner, K.; Naumann, J. Der Aufschwung (1960-1967); Klett: Stuttgart, Germany, 1977, ISBN 3-12-923940-5.

68. Coombs, P.H. Educational Planning; A Directory of Training and Research Institutions; UNESCO-IIEP: Paris, France, 1968.

69. Ferrez, J. Regional Inequalities in Educational Opportunity. In Ability and Educational Opportunity; Halsey, A.H., Ed.; OECD: Paris, France, 1961; pp. 69-87.

70. Diederich, J. Die Landschulreform im Spiegel der Pädagogischen Zeitschriften; Beltz: Weinheim, Germany, 1967.

71. Bormann, M. Bildungsplanung in der Bundesrepublik Deutschland: System und Grundlagen; Westdeutscher Verlag: Opladen, Germany, 1978, ISBN 978-3-531-11449-1.

72. KMK. Bedarfsfeststellung 1961 bis 1970 für Schulwesen, Lehrerbildung, Wissenschaft und Forschung, Kunst und Kulturpflege; Klett: Stuttgart, Germany, 1963.

73. Deutscher Bundestag. Unterrichtung Durch die Bundesregierung: Bildungsgesamtplan; Drucksache 7/1474: Bonn, Germany, 1973.

74. Rolff, H.G.; Klemm, K.; Hansen, G. Die Stufenschule: Ein Leitfaden zur Kommunalen Schulentwicklungsplanung; Klett: Stuttgart, Germany, 1974, ISBN 3-12-926950-9.

75. Heinz, R.; Schier, M.-L. Schulentwicklungsplanung vor Verabschiedung des Bildungsgesamtplans. Eine Auswertung kommunaler Pläne; Arbeiststelle für Schulentwicklungsforschung (AFS): Dortmund, Germany, 1974.

76. Wagener, F. Neubau und Verwaltung. Gliederung der öffentlichen Aufgaben und ihrer Träger nach Effektivität und Integrationswert, 2nd ed.; Duncker \& Humblot: Berlin, Germany, 1974.

77. Arneth, G. Schulentwicklungsplanung im Rahmen regionaler Strukturplanung. Z. Für Pädagogik 1972, 18, 829-850.

78. Schulz, D. Pädagogisch Relevante Dimensionen Konkurrierender Schulentwicklungsplanung: Bestandsaufnahme und Qualitative Analyse der Schulentwicklungsplanung in den Ländern der Bundesrepublik Deutschland; Lang: Frankfurt (Main), Germany, 1981 ISBN 3-8204-6942-7.

79. Rauch, N.; Schröder, T. Zur Methodik der Schulentwicklungsplanung. Gesamtschulen: Informationsdienst, Nachrichten, Berichte, Bibliographen, Dokumente 1970, 3, 31-50.

80. Deutscher Städtetag. Hinweise zur Schulentwicklungsplanung; Deutscher Städtetag: Köln, Germany, 1972.

81. Kommunale Gemeinschaftsstelle. Organisation der Schulentwicklungsplanung; KGSt-Bericht 10/1975: Köln, Germany, 1975.

82. Martinsen, R.; Back, H.-J.; Schultze, H.-D. Regionale Schulentwicklungsplanung: Grundlagen, Methoden, Realisierung; Forum-Verlag: Stuttgart, Germany, 1974

83. Brixner, W. Universität Tübingen, Tübingen, Germany, 1972.

84. Furck, C.-L. Neue Dimensionen in den Schulentwicklungsplänen? Z. Für Pädagogik 1972, 18, 803-828.

85. Schütz, P.; Schütze, A. Schulentwicklungsplanung: Eine neue Chance für Reformen? Bild. Und Erzieh. 1975, 28, 348-356. [CrossRef]

86. Bartl, W.; Papilloud, C. Measuring "equivalent living conditions"? The use of indicators in German federal spatial planning. Stat. J. IAOS 2020, 36, 375-399. [CrossRef]

87. Russig-Kallfass, S. Handlungsspielräume Kommunaler Schulentwicklungsplanung: Zur Theorie und Praxis Dezentraler Schulpolitik; Beltz: Weinheim, Germany, 1977, ISBN 3-407-58003-7.

88. Böttcher, W.; Budde, H.; Klemm, K.; Meergans, H. Schulentwicklungsplanung: Eine Handreichung für die Neuen Länder; Max-TraegerStiftung: Frankfurt (Main), Germany, 1992. 
89. Wenk, S. Das Ringen um die “Wirklichkeit der Dorfschule” und die Reform des ländlichen Schulwesens in den 1960er Jahren. In Wissen Machen: Beiträge zu Einer Geschichte Erziehungswissenschaftlichen Wissens in Deutschland Zwischen 1945 und 1990; Reh, S., Glaser, E., Behm, B.L., Drope, T., Behm, B., Eds.; Beltz Juventa: Weinheim, Germany, 2017; pp. 143-163, ISBN 3-7799-3516-3.

90. Aurin, K. Regionale Schulplanung unter veränderten Bedingungen: Probleme, Forschungsaufgaben und neue Planungsorientierungen. In Regional Differenzierte Schulplanung unter Veränderten Verhältnissen: Probleme der Erhaltung und Strukturellen Weiterentwicklung Allgemeiner und Beruflicher Bildungseinrichtungen; Aurin, K., Ed.; Vincentz: Hannover, Germany, 1984; pp. 9-24, ISBN 3-87870-753-3.

91. Trotha, T.V. Sicherung einer wohnungsnahen Schulversorgung durch die Länder. Inf. Zur Raumentwickl. 1981, 8, 655-661.

92. Derenbach, R.; Gatzweiler, H.-P. Sicherung der Schulstandorte unter veränderten Rahmenbedingungen-Eine gemeinsame Aufgabe von Raumordnungs- und Bildungspolitik. Inf. Zur Raumentwickl. 1988, 15, 407-416.

93. Schorb, A.O. Entwicklungen im Schulwesen eines Flächsenstaates am Beispiel Bayern. In Gegenwärtige Probleme; Projektgruppe Bildungsbericht, Ed.; Rowohlt: Reinbek bei Hamburg, Germany, 1980; pp. 759-816, ISBN 3-499-17338-7.

94. Döring, P.A. (Ed.) Große Schulen oder kleine Schulen? Zur Dimensionierung von Bildungseinrichtungen; Piper: München, Germany, 1977, ISBN 3-492-02320-7.

95. Wiese, W. Zurück ins Dorf! Oder: Die Wiedereinrichtung wohnortnaher kleiner Grundschulen in Baden-Württemberg. Inf. Zur Raumentwickl. 1988, 7, 457-464.

96. Kramer, C.; Bauer, L. Das Standortnetz von Grundschulen in Baden-Württemberg im Wandel—Entwicklungen und Einflussfaktoren. In Bildungsforschung Mit Daten der Amtlichen Statistik; Fickermann, D., Weishaupt, H., Eds.; Waxmann: Münster, Germany, 2019; pp. 87-104.

97. Köhler, H.; Lundgreen, P. Allgemein Bildende Schulen in der Bundesrepublik Deutschland 1949-2010; ZA8570 Datenfile Version 1.0.0; GESIS: Köln, Germany, 2015. [CrossRef] 